Maurer School of Law: Indiana University Digital Repository@Maurer Law

Articles by Maurer Faculty

Faculty Scholarship

1987

\title{
Why the McCarran-Walter Act Must Be Amended
}

John Scanlan

Indiana University Maurer School of Law, scanlan@indiana.edu

Follow this and additional works at: http://www.repository.law.indiana.edu/facpub

Part of the Immigration Law Commons, and the Legislation Commons

\section{Recommended Citation}

Scanlan, John, "Why the McCarran-Walter Act Must Be Amended" (1987). Articles by Maurer Faculty. 2494.

http://www.repository.law.indiana.edu/facpub/2494

This Article is brought to you for free and open access by the Faculty Scholarship at Digital Repository @ Maurer Law. It has been accepted for inclusion in Articles by Maurer Faculty by an authorized administrator of Digital Repository @ Maurer Law. For more information, please contact wattn@indiana.edu.

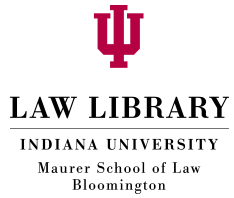




\title{
Why the McCarran-Walter Act Must Be Amended
}

\author{
JOHNA. SCANLAN
}

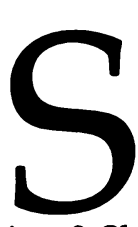

hould our society, founded on the principle of free debate about important public issues, cease the practice of excluding aliens because of their beliefs, their political utterances, or their party affiliations? Should the academy, which has long been particularly affected by the ideological provisions of United States immigration law, take an active role in seeking to repeal or liberalize these provisions? These are the questions presented, not for the first time, by current efforts in the House of Representatives (H.R. 1119, introduced by Representative Barney Frank [D-MA] to repeal the ideological provisions of the McCarran-Walter Act. Both questions should be answered affirmatively, for reasons grounded not only in concerns about the effects of present law on academic freedom, but also on the lessons the academy should learn from its past.

Few would contend that current governmental attempts to control what is researched or taught in American colleges and universities approach the level or reflect the virulence so characteristic of the late 1940s and early 1950s, when Cold-War hysteria was at its height. Although official attacks on individual professors identified as Marxist or "radical" do occur (and may in fact be increasing in frequency), no contemporary analogue exists for the concerted attempt to purge institutions of higher education of "Red-ucators" and "fellow travellers" that was promoted by Congress and many state legislatures and embraced with such vigor by so many university administrators and boards of trustees during the McCarthy era. Like their counterparts of that era, organizations such as "Accuracy in Academia" apparently are motivated by the desire to impose a conservative orthodoxy on every branch of learning. To date, however, their efforts have met with more ridicule than support.

Although "Olliemania" may shift the balance slightly, a national consensus appears to have emerged slowly over the last quarter-century that the threat to United States security interests posed by Communist movements abroad is manageable and ought not to be combatted internally by "witch hunts" that pose their own immediate threats to American freedom. Congress has largely concurred, as have the courts. Since the early 1960s, standing "investigating committees" have

JoHn A. SCANLAN is associate professor of law at Indiana University. been disbanded at the national and state levels, the First Amendment rights of academics have been affirmed in a variety of legal contexts, and "loyalty oaths" have been almost totally abolished.

We must not minimize the importance of these changes; but we must be careful not to exaggerate them. Particularly during the Reagan years, "national security" has been offered as a talismanic justification for a wide variety of governmental practices impinging directly on the academy. In its name, barriers have been imposed on American scholars seeking to conduct research in Cuba, access has been restricted to documents formerly available from government agencies, and attempts have been made to deny foreign scholars access to "sensitive" - but hardly secret or classified-information and technology. More important, perhaps, "national security" grounds have been used to invoke the long-standing power of the federal government to bar or expel aliens whose views the present administration considers dangerous, either because they advocate the "economic, international, and governmental doctrines of world communism," are present or former members of Marxist or socialist political parties, or threaten through their writings and their speech "to engage in activities which would be prejudicial to the public interest." Most of the aliens affected by the exercise of this power have been foreign academics, journalists, creative writers, or public officials who have been invited to teach or lecture at American universities or professional symposia.

7 Then The use of immigration law to stifle dissent and attempt to hold unpopular ideas at bay is nearly as old as this nation. However, the explicit nexus between national attitudes toward foreigners, "alien ideologies," and limited academic freedom was not forged until after the Russian Revolution, two world wars, and the emergence of the United States as a "world power."

In 1798, when Congress enacted the infamous Alien and Sedition Acts, it made specific provision for deporting "alien enemies" (the Alien Enemy Act) and other aliens whom the president considered "dangerous to the peace and safety of the United States, or shall have reasonable grounds to suspect are concerned in any treasonable or secret machinations against the government thereof" (the Aliens Act). ${ }^{1}$ Two years later, responding to widespread popular opposition, Congress permitted the little-used Aliens Act to lapse. Most of the 


\section{"The use of immigration law to stifle dis- sent and attempt to hold unpopular ideas at bay is nearly as old as this nation."}

opposition resulted from revulsion about how the related Sedition Acts were employed by the Federalist party against its domestic political enemies. In an important but seldom quoted dissent written in 1961, Justice Hugo Black noted:

[t]he enforcement of these statutes... constitutes one of the greatest blots on our country's record of freedom. Publishers were sent to jail for writing their own views and for publishing the views of others. The slightest criticism of Government or policies of government officials was enough to cause biased federal prosecutors to put the machinery of Government to work to crush and imprison the critic. Rumors which filled the air pointed the finger of suspicion at good men and bad men alike, sometimes causing the social ostracism of people who loved their country with a deathless devotion. Members of the Jeffersonian Party were picked out as special targets so that they could be illustrious examples of what could happen to people who failed to sing paeans of praise for current federal officials and their policies. ${ }^{2}$

However, the Alien Enemy Act-which had not been invoked during that turbulent era-was never repealed. Nearly two hundred years after its passage, it continues to provide authorization for removing "natives, citizens, and subjects" of countries in a "state of declared war" against the United States.

Slightly more than a century later, the Congress, reacting to the assassination of President William McKinley, enacted permanent legislation making simple advocacy of, or belief in, "the overthrow by force or violence of the United States or of all governments or of all forms of law" a ground for excluding an intending immigrant from the United States. This attack on "anarchism" clearly was responsive to a single act of unusual violence; yet it also reflected broader national concerns about "radicals" in the labor movement (and the "radical" demands for representation, higher wages, and better working conditions that the embattled unions were making), and a growing belief that the "new immigrants" from Eastern and Central Europe brought with them political values that threatened the existing social and political status quo. Advocacy and belief were thus put on the same moral plane as a demonstrated intent to assassinate political officials.

During and immediately following the First World War, additional legislation was adopted expanding the class of excludable aliens to include those advocating or teaching unlawful destruction of property, and the first statute providing for the deportation of subversives since 1798 was enacted to permit the expulsion of aliens believed to favor such destruction, or to be "anarchists, or... who believe in or advocate the overthrow by force or violence of the government of the United States,... or who disbelieve in or are opposed to organized government, or who teach the duty, necessity, or propriety of the unlawful killing of any officer... of the government of the United States or of any other organized government...." Another statute made deportable "aliens who wrote, published, circulated, or possessed subversive literature. ${ }^{\prime 3}$ The primary targets of this legislation were still anarchists, although implicit recognition was also given to the dangers to the United States believed posed by Communist revolutionaries.

Yet the bulk of the American electorate in 1917 and 1918 was probably more concerned about the dangers posed by "alien enemies" (i.e., German nationals)-and anyone believed insufficiently patriotic or unduly supportive of the German cause or a premature peace. Those concerns were shared by a significant number of American college administrators. For the first time, nativist and chauvinist sentiment was translated directly into a major attack on academic freedom. Symbolically led by Columbia University President Nicholas Murray Butler (who, according to Richard Hofstadter and Walter Metzger, "formally withdrew the privilege of academic freedom for the duration of the war" $\left.{ }^{\prime \prime}\right)$, universities across the nation began imposing "loyalty oaths," censuring pro-German or pacifist sentiments, and firing professors who overstepped the ill-defined line of compelled political conformity. Although Harvard faced down a donor threatening to cancel a $\$ 10,000,000$ bequest unless the university demoted an openly pro-German professor ${ }^{5}$ and other institutions resisted pressures brought by public opinion, financial contributors, and angry trustees, the profession generally paid more heed to concerns about patriotism than it did to issues of academic freedom. The AAUP Committee on Academic Freedom in Wartime concluded, among other things, that professors of Germanic origin or sympathy were obligated "to refrain from public discussion of the war; and in their private intercourse with neighbors, colleagues, and students, to avoid all hostile or offensive expressions concerning the United States or its Government." As a 


\section{"President Truman, in the message accom- panying his unsuccessful veto of the McCarran-Walter Act, objected strenuous- ly to its provisions."}

result, the committee believed that universities were entitled to dismiss faculty members who defaulted on this "obligation."

Excepting essentially punitive measures aimed at excluding former Nazis, all subsequent immigration legislation barring "subversives" has focussed explicitly-although not exclusively-on members of (or on persons "affiliated with") the Communist party or other organizations regarded as sympathetic to its aims, and has also provided specific authority to exclude or deport those who "teach" or "advocate" its "doctrines." Additional authority has also been granted to the immigration service to bar any individual whose expression of political views is regarded as contrary to "the public interest." Thus, the Smith Act in 1940, the Displaced Persons Act in 1948, the Internal Security Act in 1950, and the McCarran-Walter Act in 1952 all linked "national security" to the belief, expressed most directly by the Senate Judiciary Committee in 1950, that

Communism is of necessity an alien force. It is inconceivable that the people of the United States would, of their own violition [sic] organize or become part of a conspiracy to destroy the free institutions to which generations of Americans have devoted themselves. The tremendous political freedom and the corollary standard of living of the United States have given this country a national entity and heritage far superior to anything which human society has created elsewhere....

In the light of these facts, it is not strange that the vast majority of those who would establish a Communist dictatorship in this country come from alien lands; and it is easy to see that the forces of world Communism must have or find ways and means of getting their minions into this country. ${ }^{7}$

The notion that Communism was a fundamentally "alien" ideology-staffed by agents who took all of their orders from Moscow and directed inevitably toward "subversion," "world revolution," and the destruction of all "democratic institutions" (including the universities)-was not a surprising view. Americans had been deeply distrustful of the Russian Revolution from its inception and had supported early attempts to overthrow it militarily. Most had stood behind Attorney General Mitchell Palmer in 1919, when he used the immigration laws to imprison thousands of aliens (and to deport over 500) whom he identified as "Reds" about "to rise up and overthrow the Government at one fell swoop." ${ }^{8}$ The American people were well aware of the Stalinist purges in the 1930s, and, particularly in the era of the Berlin airlift, the first Soviet nuclear explosion, and the Hiss and Rosenberg espionage cases, could easily believe that the "Cold War" was a short step away from a "shooting war." In the interim, if the evidence from Poland, Czechoslovakia, Hungary, and China could be trusted, the Soviets seemed to be gaining an upper hand.

When attitudes toward the Soviet Union and the assignation of blame for its successes became a political issue in the late 1940s and early 1950s, it was thus not surprising that virtually all Republicans and most Democrats sought to demonstrate their foresight or their purity by ferreting out Communists, their overt sympathizers, and those who had been "duped," and therefore had failed to be sufficiently critical of Communist philosophy, programs, accomplishments, or leaders. Nor was it surprising that the process of purgation quickly reached the universities.

There it manifested itself in two ways. The first-and most important-involved the many instances in which university administrators, acting on their own or in response to pressure from alumni, press, students, congressional or state investigators, and organizations such as the National Council for American Education, threatened, censured, or fired faculty members who refused to take loyalty oaths or to testify before investigating committees, admitted past or present Communist party membership or affiliation, or otherwise manifested their "disloyalty" by expressing Marxist or Socialist ideas or taking active roles in various "subversive" organizations. Fortunately for the academy, the firestorm of the McCarthy years peaked quickly and then began to subside. While it raged, however, the traditional defenders of academic freedom generally spoke with quiet voices-or lent at least limited support to the inquisition. Thus, Sidney Hook advocated stripping members of the Communist party of their teaching positions on the grounds that all had committed themselves absolutely to the "Leninist line" and followed that line "in every area of thought from art to zoology." sion of the National Education Association and the American Association of School Administrators made a similar recommendation and also argued that the "advocacy" of Communist doctrines should not be permitted in American schools, although they urged that "[y]oung citizens be 


\section{"The McCarran-Walter provisions... were not in fact used during the 1950s to deport alien academics and artists-that development had to await the Reagan ad- ministration.}

given the opportunity to learn about the principles and practices of totalitarianism, including those represented by the Soviet Union and the Communist Party in the United States." 10 The American Federation of Teachers, by official resolution, decided not to defend faculty members proven to be Communists or unwilling to deny membership. ${ }^{11}$ The AAUP, however, expressed greater concern about protecting academic freedom. While acknowledging that under some circumstances Communists could be subversive of the educational process, it objected to firing faculty members who invoked the Fifth Amendment before official investigating committees and insisted that allegations or evidence of simple party membership did not constitute grounds for disciplinary action without

evidence of unfitness to teach because of incompetence, lack of scholarly objectivity or integrity, serious misuse of the classroom or of academic prestige, gross personal misconduct, or conscious participation in conspiracy against the government. The same principle applies, a fortiori, to alleged involvement in Communist-inspired activities or views, and to refusal to take a trustee-imposed disclaimer oath. ${ }^{12}$

According to one critic of the academy during the early Cold War years, the AAUP was the only organization involved with higher education that attempted to combat political discrimination there. ${ }^{13}$

The second method of guaranteeing the "purity" of the universities was to employ the immigration laws to prevent alien Communists from teaching or lecturing within their precincts. The AAUP, which called in 1952 for the immediate "removal of legislative barriers to the visits of foreign students and scholars to this country," was not alone in objecting to the extension and use of that law to enforce intellectual and political conformity. President Truman, in the message accompanying his unsuccessful veto of the McCarran-Walter Act, objected strenuously to its provisions permitting "the Attorney General to deport any alien who has engaged or has a purpose to engage in activities 'prejudicial to the public interest' or 'subversive to the national security.' " He noted that

no standards or definitions are provided to guide discretion in the exercise of powers so sweeping. To punish undefined "activities" departs from traditional American insistence on established standards of guilt. To punish an undefined "purpose" is thought control. ${ }^{14}$
"Thought control" or not, this standardless language was incorporated into the McCarran-Walter Act, along with virtually all of the anti-" subversive" provisions adopted between 1903 and 1950. These provisions remain in effect today. They were not in fact used during the 1950s to deport alien academics and artists-that development had to await the Reagan administration. Yet many aliens were barred from entering the country. By 1955, it was estimated that "at least one hundred, and probably several hundred, foreign scientists had been denied visas" officially, and that perhaps three times that number had been effectively denied entry through consular delaying tactics. ${ }^{15}$ Scientists, however, were not the only targets; the Polish poet Czeslaw Milosz, the British novelist Graham Greene, and the French sociologist Georges Friedmann, were all early victims of the act, as were Joseph Krips, director of the Vienna State Opera, and Maurice Chevalier, the French actor and singer.

0 uch was the early history of the American attempt to immunize itself against "alien" ideas. Yet long after American universities had begun to ease up on domestic faculty dissidents, the United States government continued to use the immigration laws to insulate the nation from intellectual contagion. The list of those who have been excluded, or have faced serious immigration difficulties because of their political views, includes many famous names: novelists Gabriel Garcia Marquez, Primo Levi, Carlos Fuentes, Alberto Moravia, and Julio Cortazar; poets Dennis Brutus and Mahmoud Darwish; sociologists Ernest Mandel and Tom Bottomore; architect Oscar Niemeyer; naturalist Farley Mowatt; and a variety of public or political figures, including Chile's Hortesia de Allende, Northern Ireland's Bernadette Devlin and Ian Paisley, El Salvador's Roberto D'Aubuisson.

The list of academics excluded since 1983 also includes Dr. Joyce deWangen-Blau, a professor at the Sorbonne and noted scholar of Kurdish history and literature, denied a visa because of "links to terrorism"; Dr. Trevor Munroe, a senior lecturer at the University of the West Indies, denied a visa because of his membership in a Marxist-Leninist party in Jamaica; and two Cuban professors of philosophy, Cosme Cruz-Miranda and Arnaldo SilvaLeon, denied visas after being extended an invitation by the American Philosophical Association to 


\section{"Scores of foreign academics... have been and continue to be directly and adversely affected by the McCarran-Walter Act."}

address a conference on "Marxism in Cuba" on the grounds that it is "contrary to [American] foreign policy interests" to permit officials of the Cuban Communist Party to enter this country for any reason other than official diplomacy. During the last year, the immigration service also arrested Colombian journalist Patricia Lara as she arrived in New York to attend an academic ceremony at Columbia University, and, after holding her in prison for several days, deported her without affording her a hearing. It justified its actions by alleging that she was linked secretly to a Colombian terrorist organization. And Margaret Randall, a poet, essayist, and photographer now teaching at the University of New Mexico has been denied immigration benefits the government admits it otherwise would have granted and has been declared deportable on the sole ground that her workwhich has expressed admiration of some of the aspects of the Vietnamese, Cuban, and Nicaraguan revolutions-"advocates the economic, international, and governmental doctrines of world communism."

These examples, which include only some of the people excluded in the last thirty-five years, underscore a general truth: scores of foreign academics, creative writers and artists, and political figures from whom we as a society can learn much, even if we disagree vigorously with their politics, have been and continue to be directly and adversely affected by the McCarran-Walter Act. Others have been deterred from applying for entry either because of their sensible belief that their political views will subject them to special restrictions or actual exclusion, or because they object to revealing private political views to foreign officials. For example, the president of the Association of University Teachers, the British counterpart of the AAUP, declined an invitation to attend an AAUP meeting in the United States. He believed that present American screening procedures would make it difficult, if not impossible, to obtain the required visa. The potency of philosophical objections was explained by the general secretary of the Association of University Teachers. Writing to the AAUP about the effect of visa denials, he explained:

The record of actual refusals is small, not because of the liberal attitude of the United States Government, but because many of our members, as a matter of principle, consider it anathema to have to attest to their political views and affiliations; thus, many academics will not apply because they do not wish to place themselves in the position of signing declarations to that effect.

More perhaps than "the record of actual refusals," these words communicate the chilling effect on academic life in the United States of an immigration law that conditions entry or residency on governmental certification of "acceptable" political attitudes. ${ }^{16}$

$\mathrm{T}$ The issues raised by the ideological provisions of United States immigration law are not, of course, only of concern to the academy. To the extent that an American brand of political orthodoxy is required of labor leaders, entertainers, bureaucrats, intending students, or any other foreign national, the spectre of "thought control" arises. Avoiding unnecessary intrusions into the arena of "free speech" while protecting political and social institutions from violent disruption is a responsibility that every "liberal" democracy faces. Since every resident of the United States will be more or less free-and more or less securedepending on what criteria are employed to screen out or control unwelcome or dangerous utterances, it is imperative that those criteria be protective of the entire population, and not just particular segments of it. Because protection is the question, though, actual risks have to be taken into account. While the legal system might reject the contention that those in the academy are deserving of special constitutional rights, it ought to conclude that the dangers posed by academic discourse, however radical that discourse might seem, do not portend the violent overthrow of American institutions and must be accepted to preserve the overriding values of a liberal society.

If immigration were not at issue, that conclusion would be amply supported by the First Amendment, which prohibits Congress from making any "law... abridging the freedom of speech, or of the press." Although the amendment's prohibitions are absolute, judicial interpretation has established a variety of exceptions, permitting legislatures, for example, to pass certain types of libel laws, or certain laws prohibiting the distribution of pornography, or the utterance of certain words deemed "obscene" on the public airwaves or unduly disruptive when expressed in the nation's secondary school classrooms. But particularly when "political speech" is involved, a heavy presumption of constitutional protection arises. That presumption 


\section{"The dangers posed by academic discourse, however radical that discourse might seem, do not portend the violent over- throw of American institutions.'}
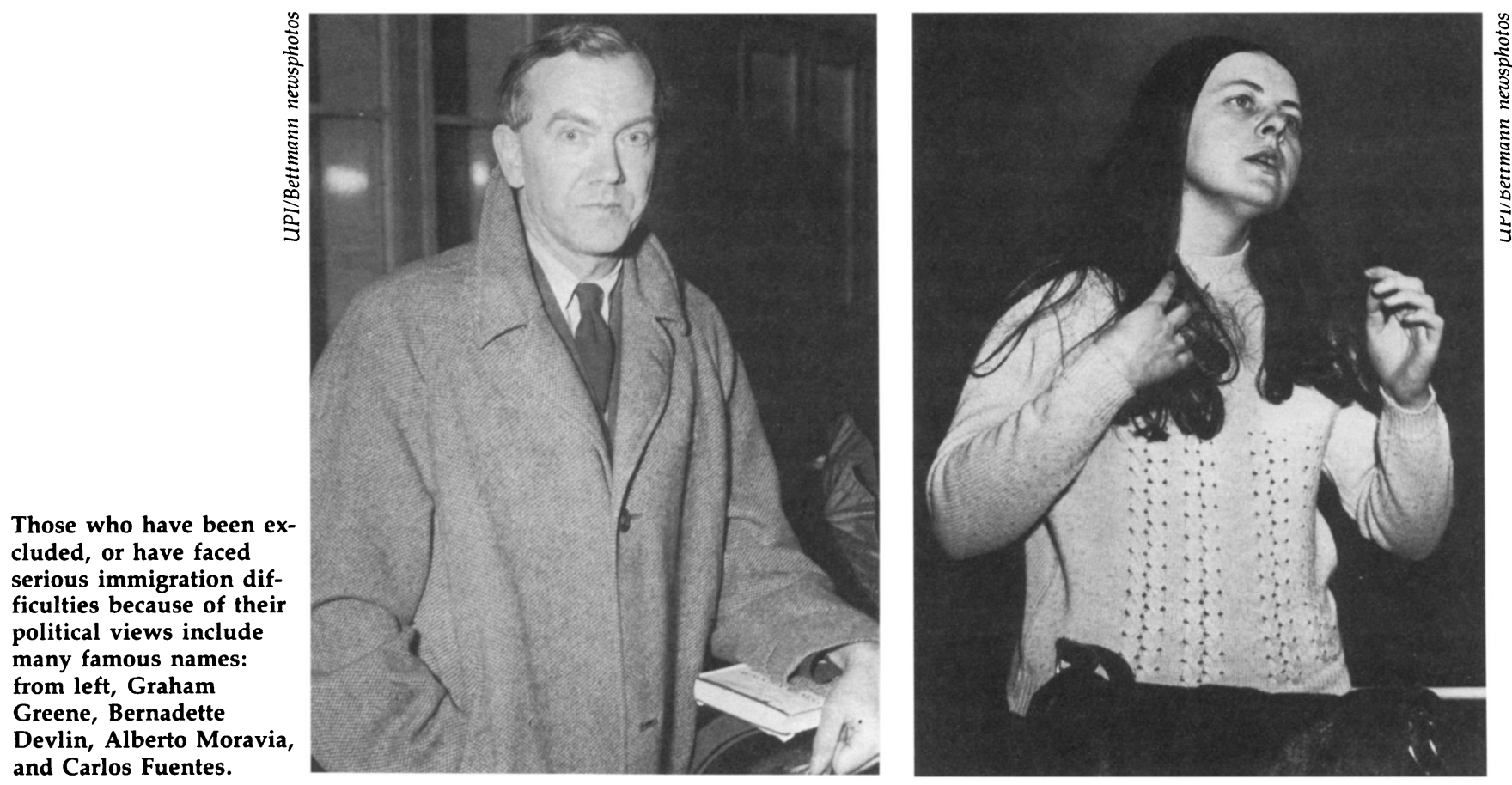

grows when political opinions are expressed by college and university faculty. For as the Supreme Court noted in Sweezy v. New Hampshire thirty years ago:

the essentiality of freedom in the community of the American universities is almost self-evident. No one should underestimate the vital role in a democracy that is played by those who guide and train our youth. To impose any strait jacket upon the intellectual leaders in our colleges and universities would imperil the future of our Nation.... Teachers and students must always be free to inquire, to study and to evaluate, to gain new maturity and understanding; otherwise our civilization will stagnate and die. ${ }^{17}$

This "freedom of responsible inquiry," as the Court noted in another case, is the single value that defines democratic discourse generally and its particular and specialized manifestation within the university. Therefore, the state must permit faculty and students alike "to sift evanescent doctrine" and "look into the meaning of social and economic ideas, into the checkered history of social and economic doctrine." 18

Not only is disinterested "inquiry" protected, but "advocacy" as well:

The constitutional guarantees of free speech and free press do not permit a State to forbid or proscribe advocacy of the use of force or of law violation except where such advocacy is directed to inciting or produc- ing imminent lawless action and is likely to incite or produce such action.... '[T]he mere abstract teaching [of] the moral propriety or even the moral necessity for a resort to force and violence, is not the same as preparing a group for violent action and steeling it for such action.' ${ }^{\prime 19}$

In other words, the beliefs of a speaker may stand in opposition to the political status quo, and the speaker's words may indicate the "moral necessity" of overthrowing that status quo through violence; yet the danger posed by such advocacy is not sufficient to overcome the presumption in favor of free expression embodied in our political system. That presumption does not-or at least should not-give way when "revolutionary ideas" are at issue. Again, the language of Justice Black's earlier dissent is eloquent:

the question... is whether Congress has the power to outlaw an association, group, or party either on the ground that it advocates a policy of violent overthrow of the existing Government some time in the future or on the ground that it is ideologically subservient to some foreign country. In my view, neither of these factors justifies an invasion of the rights protected by the First Amendment. Talk about the desirability of revolution has a long and honorable history, not only in other parts of the world, but also in our own country. This kind of talk, like any other, can be used at the wrong time and for the wrong purpose. But under our system of Government, the remedy for this danger must 


\section{"Particularly when 'political speech' is in- volved, a heavy presumption of constitu- tional protection arises.}

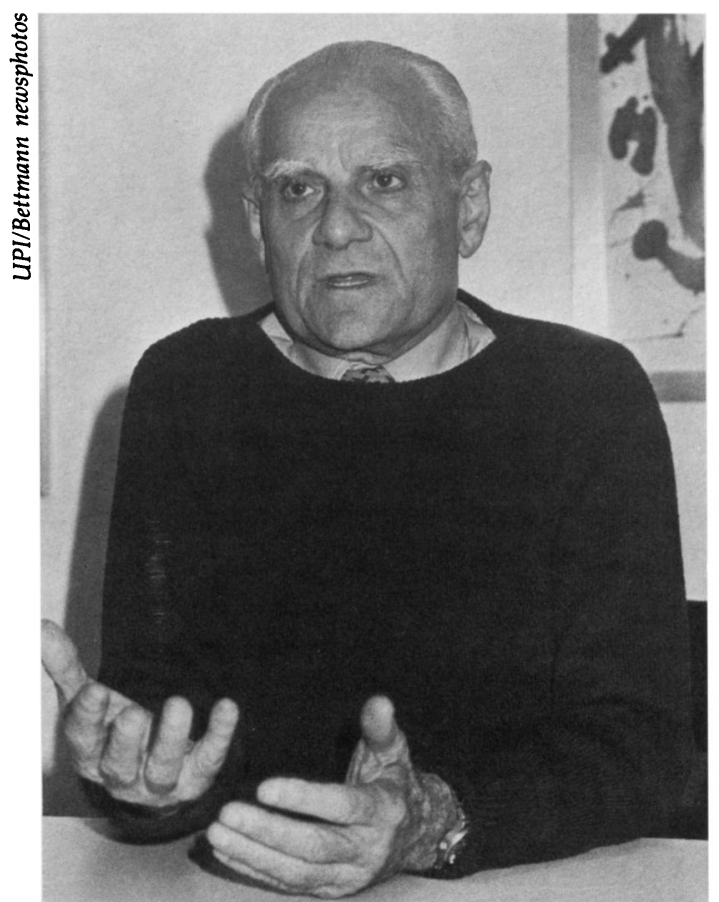

be the same remedy that is applied to the danger that comes from any other erroneous talk-education and contrary argument. ${ }^{20}$ (emphasis added)

$\mathrm{I}$ $f$ this mode of thinking about dissent-particularly when expressed in a forum where competing views are likely to be heard-were applied to aliens, the consequences would be obvious. No longer would it be permissible to exclude or deport people because of their "subversive" beliefs, their "advocacy" of particular forms of revolutionary change, or even their membership in "ideologically subversive" but nonviolent political organizations. Instead, the government would be compelled to show that "dangerous" thoughts or speech had been accompanied by "dangerous" deeds-or had led directly to their accomplishment. Justice Holmes's hoary adage, "the most stringent protection of free speech would not protect a man falsely shouting fire in a theater and causing a panic," would be tested. In the absence of evidence of an actual panic or the virtual certainty that one would ensue, the shouts, however false and misguided, would not be punished.

Thus, Ian Paisley would no longer be excludable because he might preach religious hatred in Northern Ireland to an audience in New York-although the story would be different if he brought a bomb with him to blow up St. Patrick's Cathedral. Sim- ilarly, the government, were it to insist on excluding Professor deWangen-Blau again because of alleged "links with terrorism" would be required to answer several questions: What were those "links with terrorism"? Would any field research in politically turbulent Iran or Iraq disqualify Dr. deWangen-Blau from entry? Were her "links" in any way associated with active participation in terrorist acts abroad? Did they realistically portend that she would engage in, or actively incite, criminal or terrorist acts in the United States if afforded entry? Similar, and perhaps more difficult, questions would have to be answered if the government were again to refuse admission to Cuban scholars who sought only to enter for the period of an academic conference, and who were not identified by the Department of State as members of a terrorist group. No longer would it be permissible to invoke "[American] foreign policy interests" without explaining what foreign policy interests would be implicated by permitting attendance at an academic conference, or indeed, if such interests existed, how they could conceivably outweigh the clear interest that the United States has in being regarded by the rest of the world as an "open" society. As importantly, the government would be required to explain why such interests outweighed those of the American academics who extended the invitation to learn at first hand more 


\section{"The Supreme Court has not been willing to admit noncitizens fully into the 'marketplace of ideas."}

about Marxism in Cuba-a country to which, because of official action by the Reagan administration, most American citizens and many scholars are effectively barred from traveling at present.

Exclusion or deportation on ideological grounds in many other situations where it is currently permitted no longer would be possible, no matter what questions were asked. Thus attendance at a Moscow peace conference twenty-five years agoDr. Jim Harding's "offense" -or poems praising "Fidel" or "Che" - one of Margaret Randall's alleged peccadillos-would simply have no legal relevance.

Unfortunately for alien academics and their American faculty sponsors, the Supreme Court has not been willing to admit noncitizens fully into the "marketplace of ideas." While acknowledging that American faculty members have a constitutionally protected right to "receive information" from foreign scholars, it has refused to give that "right" any substance. Instead, as the law presently stands, "plenary congressional power to make policies and rules for the exclusion of aliens" has been reaffirmed, and any "facially legitimate and bona fide reason" offered by the government for keeping unwanted aliens out will suffice. Even if the reason offered by the executive or Congress for excluding an alien is the likelihood that he or she will present an unorthodox Marxist economic theory to a scholarly conference, that reason will not be tested "by balancing [it] against the First Amendment rights of those who seek personal communication with the alien." 21 The constitutional situation is considerably more murky for aliens like Margaret Randall, who face "deportation" from the United States rather than initial exclusion. ${ }^{22}$ Yet the provision of the McCarran-Walter Act that permits her deportation because of her "advocacy" and "beliefs" has thus far withstood challenge in the lower federal courts.

Legislation of the sort currently proposed is therefore necessary if the bearers of "alien ideas" are to be accorded a genuine welcome. In 1977, Congress passed the "McGovern Amendment." That statute obligates the secretary of state to admit any alien excludable by virtue of simple mem-

\section{A National Embarrassment STENY H. HOYER}

Perhaps the greatest tribute Congress could pay to the Constitution this bicentennial year is to cleanse our statute books of laws that mock our freedoms. One such law is the McCarranWalter Act of 1952, a legal relic of McCarthyism that has somehow remained on the books despite its affront to free speech at home and the embarrassment it causes us abroad. .

Such a law seems surprising in this free land of ours. It is a basic premise of our system that the best defense against a bad idea is a good idea-not a censored idea. Making policy in a democracy requires an infusion of perspectives from all sources, whether we like what they have to say or not.

McCarran-Walter, however, puts government in the business of selecting which speakers and opinions are appropriate for an American audience. While we like to think of our society as a free market for ideas, the McCarran-Walter Act serves as ideological protectionism. It is censorship by any other name.

It is a further irony that whatever questionable foreign policy gains we might make by excluding visitors under this law are undermined by the foreign policy losses because of it. McCarranWalter is viewed as a violation of our Helsinki commitments on travel, movement, human contacts and the free flow of information. Though a trifle compared with Soviet and East European Helsinki violations, it gives those nations a convenient way to

defuse our criticism of their massive human rights abuses.

When we raise the problem of Soviet emigration restrictions, they divert the discussion to McCarran-Walter and say that it discriminates against communist nations. When we went to Ottawa in 1985 for the Human Rights Experts Meeting, we were forced to explain why Canadian author Farley Mowat had just been excluded from the United States. We faced the same unnecessary questions at last year's Human Contacts Meeting in Bern and at the ongoing Helsinki Review Meeting in Vienna. The McCarran-Walter Act has become a needless diplomatic distraction.

A bill now pending in the House, sponsored by Rep. Barney Frank, would repeal the ideological exclusion provisions of the McCarran-Walter Act by prohibiting the government from barring entry on the basis of ideology or affiliation. At the same time it would address national security concerns by toughening restrictions on terrorists and excluding anyone expected to commit a criminal act that could endanger our national security.

In this year of the Constitution, it is time to restore our visa laws to their proper foundation, the Bill of Rights.

Representative Steny H. Hoyer of Maryland is chair of the Commission on Security and Cooperation in Europe. () Washington Post, September 2, 1987. Reprinted by permission. 


\section{"An elaborate and standardless statute, in- herited from the McCarthy era, still per- mits the government to exercise broad discretion."}

bership in the Communist party unless he "determines that admission of such alien would be contrary to the security interests of the United States." Nothing really limits his power to make that determination, however, nor does the McGovern amendment protect those excluded because of their ideas rather than their affiliations. Indeed, an elaborate and standardless statute, inherited from the McCarthy era, still permits the government to exercise broad discretion in imposing barriers against those with unorthodox or threatening views.

$\mathrm{T}$ The "'marketplace of ideas," whether regarded as the basis of democratic government or the principle upon which universities are built, is always an ideal. Nowhere is it to be found in a pure form. Always, the persuasive and powerful will skew the public debate in the direction they favor, withholding information and misstating facts to gain political advantage. Even in the universities, the model of open discourse and informed choice is in part a myth. The goal of academic freedom is something which always exists within the context of current academic disciplines and popular modes of thought and is always to some extent constrained by prevailing orthodoxies. Those orthodoxies are not entirely self-contained; inevitably, institutions of higher education will respond to the web of influences that tie them to the wider world. During the McCarthy era, the coercive consensus on the Cold War and the "Communist Menace" which defined much of the political universe also exerted great influence on the nation's universities, substantially limiting the range of acceptable debate. As Ellen Schrecker has noted: "Patriotism, not expedience, sustained the academic community's willingness to collaborate with McCarthyism. The intellectual independence so prized by American academics simply did not extend to the United States government. ${ }^{\prime 23}$

It is naive to think that the goal of true independence will ever be totally realized, that the bonds of hegemony will ever be totally shaken loose. Yet the academy is obligated to make the attempt. It must strive to become the open forum it has always professed to be, the agora in which no ideas are "alien," the institution where ordered discourse thrives, and the order of that discourse encourages questioning and contradiction. The present debate about immigration strictures affords an opportunity to renew that commitment.

\section{NOTES}

1. The legislative history given here and in the following paragraphs is based primarily on E.P. Hutchinson, Legislative History of American Immigration Policy, 1798-1965 (Philadelphia: University of Pennsylvania, 1981) and T.A. Alienikoff and D. Martin, Immigration Process and Policy (St. Paul, Minnesota: West Publishing Co., 1985).

2. Communist Party of the United States $v$. Subversive Activities Control Board, cited in United States Reports, vol. 367, p. 5, at pp. 155-56.

3. Act of June 5, 1920, cited in Alienikoff and Martin, p. 352.

4. The Development of Academic Freedom in the United States (New York: Columbia U. Press 1955), p. 499.

5. Ibid., pp. 502-03.

6. "Report of the Committee on Academic Freedom in Wartime," AAUP Bulletin 4 (February-March 1918): 30.

7. S. Rept. No. 1515, 81st Cong., 2d Sess. (1950), p. 782.

8. See J. Higham, Strangers in the Land: Patterns of American Nativism, 1860-1925 (New Brunswick: Rutgers U. Press 1955) pp. 229-31; Alienikoff and Martin, pp. 352-55.

9. Sidney Hook, "Should Communists Be Permitted to Teach?," NYT Magazine, 27 Feb. 1949, p. 24; quoted in B. W. Patch, "Academic Freedom," Editorial Research Reports (July 1949): 436.

10. Patch, pp. 434-35. In other words, students should be permitted to read Sidney Hook commenting on Herbert Marcuse, but not Herbert Marcuse commenting on Sidney Hook. 11. David Caute, The Great Fear (New York: Simon and Schuster, 1978), p. 406.

12. AAUP, "Academic Freedom and Tenure in the Quest for National Security," Bulletin of the AAUP, 42 (Spring 1956): 58.

13. Caute, p. 406. For the view that the AAUP did not throw itself wholeheartedly into that attempt, see Ellen Schrecker, No Ivory Tower: McCarthyism and the Universities (New York and London: Oxford University Press, 1986).

14. Immigration Bill Veto, Congressional Record (June 25, 1952), p. 8228.

15. Caute, p. 256, citing E. Shils, The Torment of Secrecy (London: Heinemann, 1956), p. 187.

16. Occasionally, the effect can extend beyond the nation's borders. For instance, Canadian Professor Jim Harding, after initially being barred from entry, was eventually given permission to enter the United States briefly in order to make airline connections to Central America, where he planned to spend his sabbatical researching the current political situation. But the INS, despite his vigorous denials of past or present Communist party membership, placed a stamp in his passport identifying him as a member of the Communist party who had been granted a special immigration "waiver." Faced with the hostility and danger that such "official" identification posed in that war-torn and ideologically volatile region, Harding cancelled his trip.

17. 354 U.S. 234, 250 (1957).

18. Wiema in v. Updegraff, 344 U.S. 183, 196 (1952) (Frankfurter, J., concurring).

19. Brandenburg $v$. Ohio, 395 U.S. 444, 447-48 (1962); Noto $v$. United States, 367 U.S. 290, 297-98 (1961).

20. Communist Party of the United States $v$. Subversive Activities Control Board, 347 U.S. at 147-148.

21. Kleindienst v. Mandel, 408 U.S. 753, 770 (1972).

22. Whether such aliens are in fact protected by the First Amendment, and may invoke its terms when contesting deportation, is a puzzling question that has generated inconsistent and impenetrable rulings from the Supreme Court. Compare Bridges v. Wixon, 326 U.S. 135 (1945); 326 U.S. 135 (1945); Harisiades $v$. Shaughnessy, 342 U.S. 580 (1952); and Galvan $v$. Press, 347 U.S. 522 (1954). Litigation in the Randall case may eventually yield some clearer answers.

23. No Ivory Tower, p. 340. 